\title{
Enhanced Production of Ethanol from Cheese whey by Agarose and Alginate immobilization of Yeast Cells
}

\author{
Smita Shrestha ${ }^{1}$, Fedip Shrestha ${ }^{2}$, Prajwal Rajbhandari ${ }^{2}$, Ramesh Baral $^{2}$ and Shyam Krishna \\ Suwal ${ }^{2}$, Jarina Joshi ${ }^{1}$ \\ ${ }^{1}$ Central Department of Biotechnology, Tribhuwan University, Kathmandu, Nepal; ${ }^{2}$ Department of \\ Biotechnology, Kathmandu University, Dhulikhel, Kavre,Nepal. \\ E-mail: jarinarjoshi@yahoo.com
}

\begin{abstract}
Yeasts cells isolated from dry yeast were immobilized in alginate and agarose to form beads. The fermentation of ethanol from cheese whey was optimized with respect to temperature, $\mathrm{pH}$, and rpm. A comparative study was performed between immobilized and free cells to get the maximum ethanol production Results revealed that $35^{\circ} \mathrm{C}$ temperature, $4.5 \mathrm{pH}$ and $60 \mathrm{rpm}$ is the optimized condition for yeast immobilized in agarose bead. Similarly, $35^{\circ} \mathrm{C}$ temperature, $5.0 \mathrm{pH}, 60 \mathrm{rpm}$ is the optimized condition for yeast immobilized in alginate bead and $35^{\circ} \mathrm{C}$ temperature, $5.0 \mathrm{pH}, 80 \mathrm{rpm}$ is the optimized condition for the free yeast cell respectively. Immobilised cell resulted $4.25 \%$ ethanol with alginate bead whereas $4.35 \%$ with agarose bead and $4.30 \%$ with free cell after three days of incubation under optimized conditions. When the same cell immobilized beads were reused, obtained $1.8 \%$ ethanol with agarose and $1.7 \%$ ethanol with alginate bead.
\end{abstract}

Keywords: Yeast cells, fermentation, whey, alginate, agarose, ethanol.

\section{Introduction}

In the present state of energy crisis, efforts are being made to reduce the dependence upon non renewable source of energy. One of such is the fuel alcohol produced by the fermentation of agricultural /agro-industrial wastes and by products ${ }^{1}$. Approximately $80 \%$ of the world supply of ethanol is produced by fermentation of sugar and starch containing crops or byproducts from industries ${ }^{2}$. Because of the increasing demand for ethanol, there is a need to search for high yielding strains and less expensive technology for production of ethanol so that it can be made available at a cheaper rate. One such process is the yeast cell immobilization which facilitates faster fermentation rates by providing higher cell densities per unit fermentation volume ${ }^{3,4}$. Ethanol fermentation from different raw materials containing carbohydrates has to be studied extensively in the future. One such is the cheese whey. The disposal of whey is a worldwide problem in dairy industry. Large quantities of whey are produced as a byproduct during the manufacture of cheese and casein; which must be processed in an environmentally acceptable form before disposal as they can quickly deplete oxygen level in natural water systems because of its high chemical oxygen demand of about $60 \mathrm{~kg}-\mathrm{m}^{-3} 5,6$. In our study, Yeast cells were immobilized on alginate agar and agarose beads. Besides this free cells were also used. A comparative study was performed between immobilized and free cell to get maximum ethanol from whey. The fermentation of cheese whey 
was optimized with respect to temperature, $\mathrm{pH}$ and rpm. This study will help in managing the dairy waste product in Nepal to convert into value added product which can be used as fuel, mouth wash, hospital solvents, perfumes etc ${ }^{7,8}$.

\section{Experimental Methods}

\section{Materials}

Dry yeast purchased from PRIME Instant Dry Yeast, Batch No: 1303B, AB Mauri India Pvt. Ltd. India. Cheese whey supplied by Nepal Dairy, Khumaltal, Lalitpur.

\section{Methodology}

The yeast cells were isolated on Yeast Extract Peptone Dextrose (YEPD) media containing $1 \mathrm{gm}$ Yeast extract, 2gm Bacto- Peptone, $2 \mathrm{gm}$ dextrose and $1.5 \mathrm{gm}$ agar in $100 \mathrm{ml}$ distilled water using spread plate technique after serial dilution of dry yeast. The isolated colonies were subcultured to get pure colony. Cells were tested for its morphology under digital microscope ${ }^{9}$. Glucose fermentation test, Urease test, starch hydrolysis test, Nitrate reduction test were performed to confirm the strain ${ }^{10}$.

The percentage of reducing sugar in whey was estimated by following the protocol provided by Miller ${ }^{11}$. Specific gravity ${ }^{12}$ and fat content ${ }^{13}$ whey was determined. Protein content in whey was estimated by Lowry's Method using the Bovine Serum Albumin as standard ${ }^{14}$.

\section{Immoblization of yeast cells}

Yeast cells were immobilized in agarose bead using ice cooled paraffin oil. After the beads formation, it was washed twice with distilled water and used for fermentation. Cell immobilized alginate beads were prepared ${ }^{3,15}$.

\section{Fermentation}

Fermentation was carried out by culturing cells in $200 \mathrm{ml}$ whey in $250 \mathrm{ml}$ conical flasks for optimization of temperature, $\mathrm{pH}$ and $\mathrm{rpm}$. Ethanols produced were estimated spectrophotometrically ${ }^{16}$.

\section{Results and Discussion}

Creamy white colonies isolated showed budding as shown in fig 1 . The motility and budding was then observed under the microscope. Table 1 showed the result obtained by several biochemical tests. According to Middlehoven WJ (2002) morphological and biochemical test predicted the isolated yeast closely resembled Saccharomyces sp.

Physical properties and chemical composition of whey in Table 2 showed that it can be an ideal carbohydrate source for ethanol production which can be further enhanced by lactose hydrolysis ${ }^{17}$. 


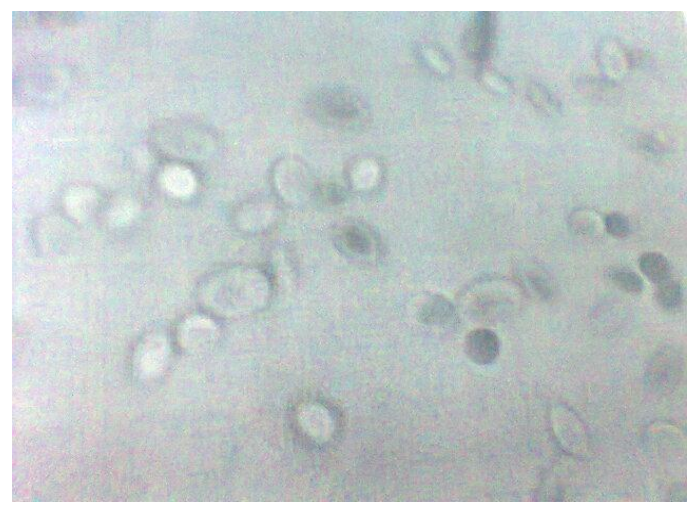

Figure1: Yeast cells observed under digital microscope.

Table1: yeast identification test

\begin{tabular}{|l|l|l|l|}
\hline Test & White colony & Yellow colony & $\begin{array}{l}\text { Saccharomyces } \\
\boldsymbol{s p} .\end{array}$ \\
\hline Glucose fermentation & positive & positive & positive \\
\hline Urease test & negative & positive & negative \\
\hline Starch hydrolysis test & negative & negative & negative \\
\hline Nitrate reduction test & negative & negative & negative \\
\hline Pellicle formation & negative & negative & negative \\
\hline Temperature & variable & variable & variable \\
\hline
\end{tabular}

Table 2: Physical properties of whey

\begin{tabular}{|lr|l|}
\hline PH & 4.0 \\
Specific gravity & & 1.0255 \\
Fat content & & $2 \%$ \\
$\begin{array}{l}\text { Protein content } \\
\begin{array}{l}\text { Reducing } \\
\text { Content }\end{array}\end{array}$ & $1.33 \%$ \\
\hline
\end{tabular}


Optimized temperature for ethanol production was found to be $35^{\circ} \mathrm{C}$ as shown in Fig 2. 4.5, 5.0 and 5.0 were found to be optimized $\mathrm{pH}$ for agarose, alginate and free cells (Fig 3). Fig 4 revealed that the optimized rpm for the systems were 120, 100 and $80 \mathrm{rpm}$ respectively. Requirement of elevated rpm in immobilized system may be due to the problem in substrate transfer ${ }^{18}$. When immobilized beads are reused, showed effective ethanol production with $40 \%$ and $41 \%$ ethanol recovery respectively by agarose and alginate beads Table 3 . Reuse of immobilized bead make the production economic ${ }^{19}$.

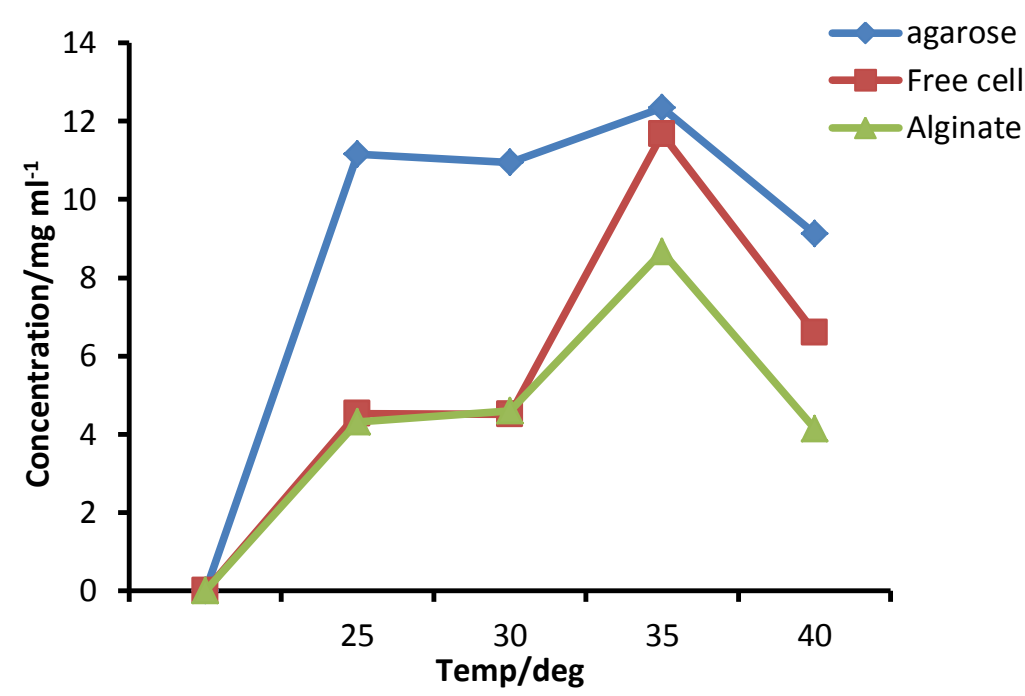

Figure 2: Effect of temperature on ethanol production.

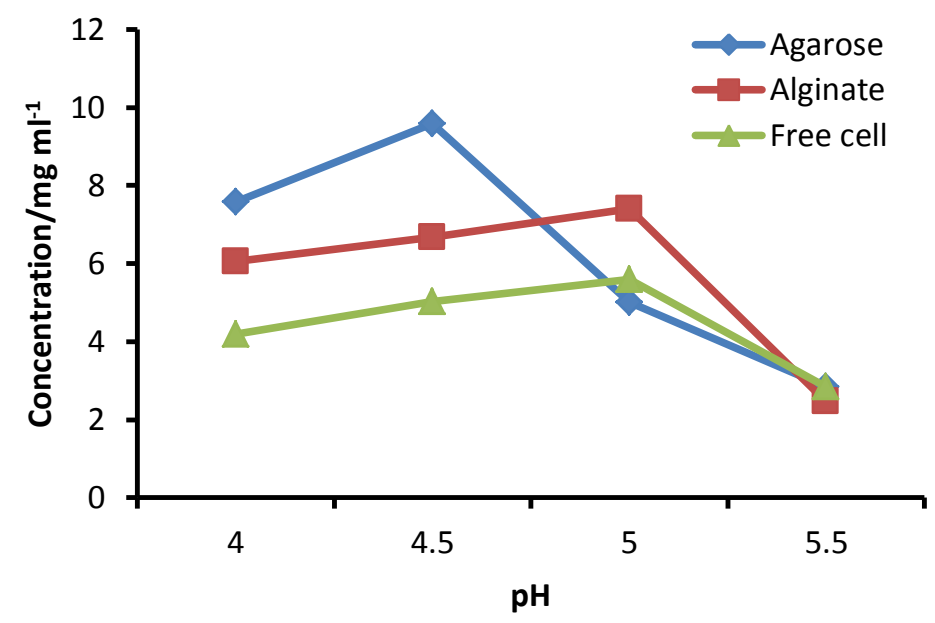

Figure 3: Effect of pH on ethanol production. 


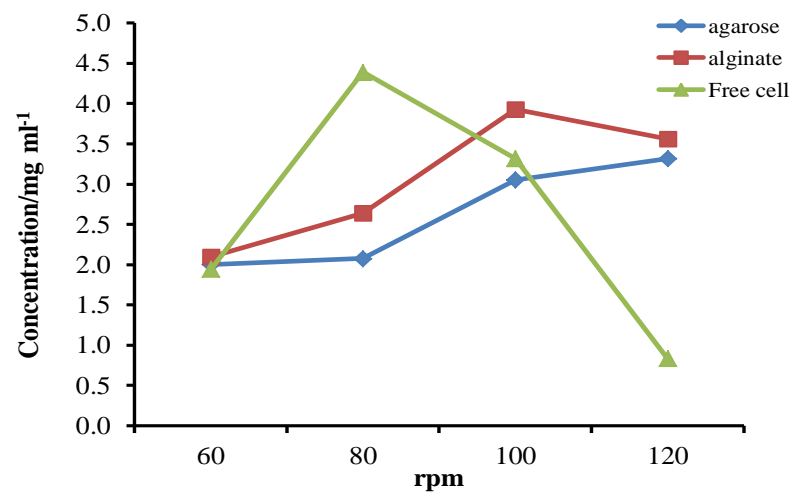

Figure 4: Effect of agitation on ethanol production.

Table 3:Recovery during reuse of immobilized beads

\begin{tabular}{|l|l|l|}
\hline Immobilised technique & Ethanol concentration $(\mathrm{mg} / \mathrm{ml})$ & Recovery percentage(\%) \\
\hline Agarose & 1.807 & 41 \\
Alginate & 1.727 & 40 \\
\hline
\end{tabular}

\section{Conclusion}

The above study suggests that yeast isolates could contribute for the production of the ethanol from cheese whey. The isolate closely resembles with Saccharomyces spp. Agarose immobilization technique displayed better ethanol yield (4.35\%) in optimized condition than alginate and free cell technology. The reuse of these beads also showed significant amount of ethanol production which indicates that immobilization technique is more economic than using free cells. Downstreaming process and wash out problems can also be minimized by this technique. Furthermore by using dairy waste (whey) as a substrate for production of ethanol is useful technology to enhance environment scenario and can be used as a biofuel and other purposes for today's perspective of world.

\section{References}

1. S. Alfenore, X. Cameleyre, L. Benbadis, C. Bideaux, J.L. Uribelarrea, G. Goma, C. MoolinaJouve and S.E. Guillouet. Appl Microbiol Biotechnol 2004, 63, 537-542

2. D. Puppan. Environemental evluation of biofuels.priodica polytechnica series-social and management sciences, 2002, 10(1), 95-116. 
3. A. Groboillot, D.K. Boadi., D. Poncelet and R. J. Neufeld. critical reviews in biotechnology, 1994, 14, 75-107

4. B.S. Yadav, Anita Sheoran, Usha Rani and Dalel Singh. Indian J. Microbiol. 1997, 37, 65-67.

5. P. Gunasekaran, and N. R. Kamini. World Journal of Microbiology and Biotechnology. 1991, 7, 551-556.

6. Ron Hamilton, Dairy Ethanol from Whey, New Zealand Institute of chemistry. June20, 2008.

7. G.E. Slapack, I. Russell and G.G. Stewart. Thermophilic Microbes in Ethanol Production. Boca Raton: CRC Press, 1987, 186.

8. S. Zafar, M. Owais, M. Saleemuddin and S. Husain. Int J Food Sci Technol. 2005, 40, 597-604

9. T. Naved, A. Kujumdzieva. Basic techniques for work with yeasts (a practical training guide) National Bank for Industrial Microorganisms and Cell Cultures , 2001, 55-56

10. W.J. Middlehoven. Mol biotechnol. 2002, 21(3), 279-292

11. GL Miller. Anal Chem. 1959, 31: 420-428

12. J. N. Gurtu, R. Kapoor, Advanced Experimental Chemistry, S Chand and Company Ltd. Ram Nagar, Delhi, 1989, 4.

13. Gekas,V.and Lopeiz-Leiva,M. Process.Biochem. 1985, 20, 2-12

14. Lowry OH, Rosebrough NJ, Farr AL, Randall RJ. J. Gen. Microbiol. 1951,131, 3017-3027,.

15. A. Nagashima. Methods in Enzymology. 1987,136, 394-405

16. A. Caputi, M. Ueda and T. Brown. Am J Enol Vitic, 1968, 19,160-65

17. A. Dahlqvist, B. Mattiasson and K. Mosbach. Biotechnol.Bioeng. 1973, 15, 395

18. M.S. Joshi, L.R. Gowda and S.G. Bhat. Biotechnology Letters, ,1987, 9:549-554

19. B.P. Sharma and R.A. Messing, Immobilised enzymes for food processing (ed.pitcher,W.H.),CRC Press,Boca Raton,Florida, 1890, 185-209 